\title{
LANDMARKS ON THE EVOLUTION OF E-COMMERCE IN THE EUROPEAN UNION
}

\author{
Laura Cătălina Țimiraş \\ "Vasile Alecsandri” University of Bacau \\ timiras.laura@ub.ro \\ Bogdan Nichifor \\ "Vasile Alecsandri" University of Bacau \\ bnichifor@gmail.com
}

\begin{abstract}
In this paper are presented and analyzed a number of statistical indicators to highlight the size and the trends in the European e-commerce market in recent years, namely - the turnover of ecommerce, the share of turnover from e-commerce in total turnover of the organizations, the share of enterprises conducting online sales in total enterprises, the population share which shop online in total population. Information is presented both aggregated and individualized, allowing highlighting disparities between European states. The paper also captures a number of correlations between the orientation to online purchasing and level of development of European countries, on the one hand and access to technology on the other. The survey is based on official statistics provided by Eurostat (data from European Union countries) and information provided by EMOTA - European Multi-channel and Online Trade Association (data pooled across all European countries).
\end{abstract}

\section{Keywords}

e-commerce market; turnover from e-commerce; orders over internet; EU market

\section{JEL Classification}

M31

The evolution of e-commerce market was marked by remarkable growth in recent years in the European market. This is not surprising in the context of increasing access of the population to technology (an increasing proportion of the population had access to the computer and used it), on the one hand, and as a result of changes made to purchase behavior and consumption, on the other hand. Thus, e-commerce is keeping up with the convenience buying process, allowing procurement in a very short time and from a large area (national or international), giving the possibility for comparing a large number of offers in terms of product characteristics and price, offering the ability to purchase products at lower prices than those of traditional distribution networks etc.

\section{Europe's place in the e-commerce world market}

Thus, in Europe in 2013 according to data from EMOTA (European Multi-channel and Online Trade Association) turnover from e-commerce reached 352 Billion Euros, representing an increase of approximately $17 \%$ over the previous year and almost 2 times bigger than the turnover of 2009. (Figure 1). 


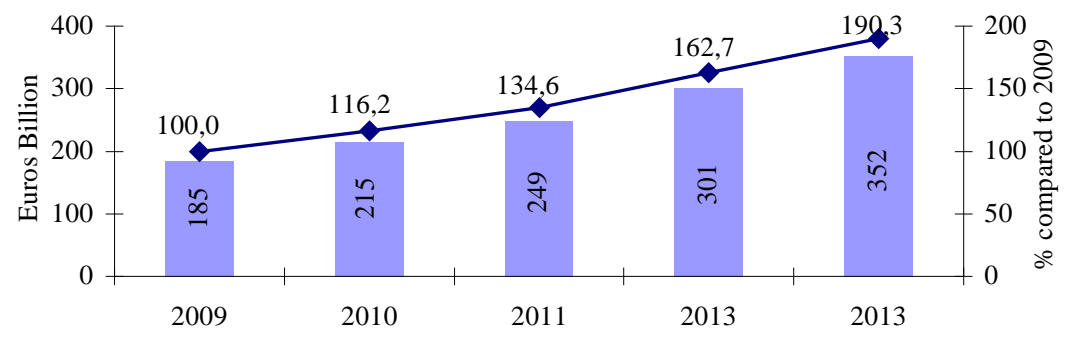

Figure 1 Evolution of E-commerce turnover in Europa, in 2009 - 2013 period (Billion Euros)

Source: Taken and worked up from E-commerce and Distance Selling in Europe Report, EMOTA (European Multi-channel and Online Trade Association)

Europe is, in fact, the largest e-commerce market relative to other major regions of the world (Asia Pacific and North America). Thus, in 2013, according to the same data sources indicated above, in Europe held in global online trade a share of 33\%, followed by Asia Pacific with 32\% and North America with 30\%. (Figure 2).

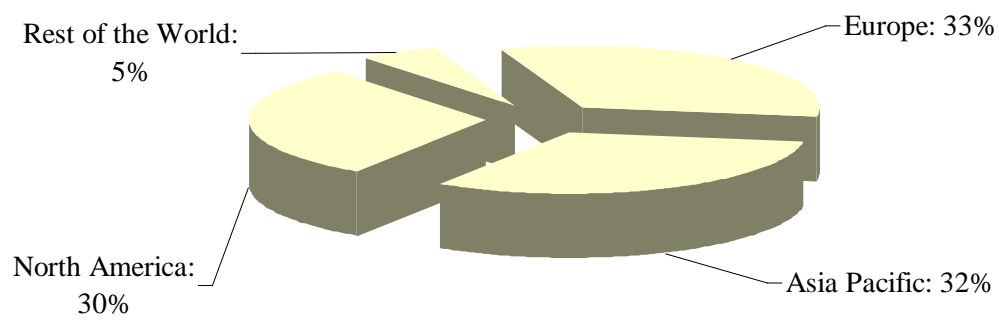

Figure 2 Share of turnover of e-commerce in the regions of the World in the total turnover of e-commerce worldwide in 2013

Source: Taken and worked up from E-commerce and Distance Selling in Europe Report, EMOTA

(European Multi-channel and Online Trade Association)

\section{Population access to technology in the European Union}

As we said before, a contributing factor in the development of electronic commerce is increased people's access to technology in recent years. In the European Union (EU28 countries), according to data for $2014,79 \%$ of the total population of $16-74$ years have used the computer in the last 12 months, which represents an increase of over $11 \%$ compared to 2009 , respectively over $21 \%$ compared to 2007 . Regarding the data for individual countries, there were major differences, the most spectacular growth was recorded in general in the former communist countries and in some of the less developed countries in the older EU members (Greece, Portugal). 


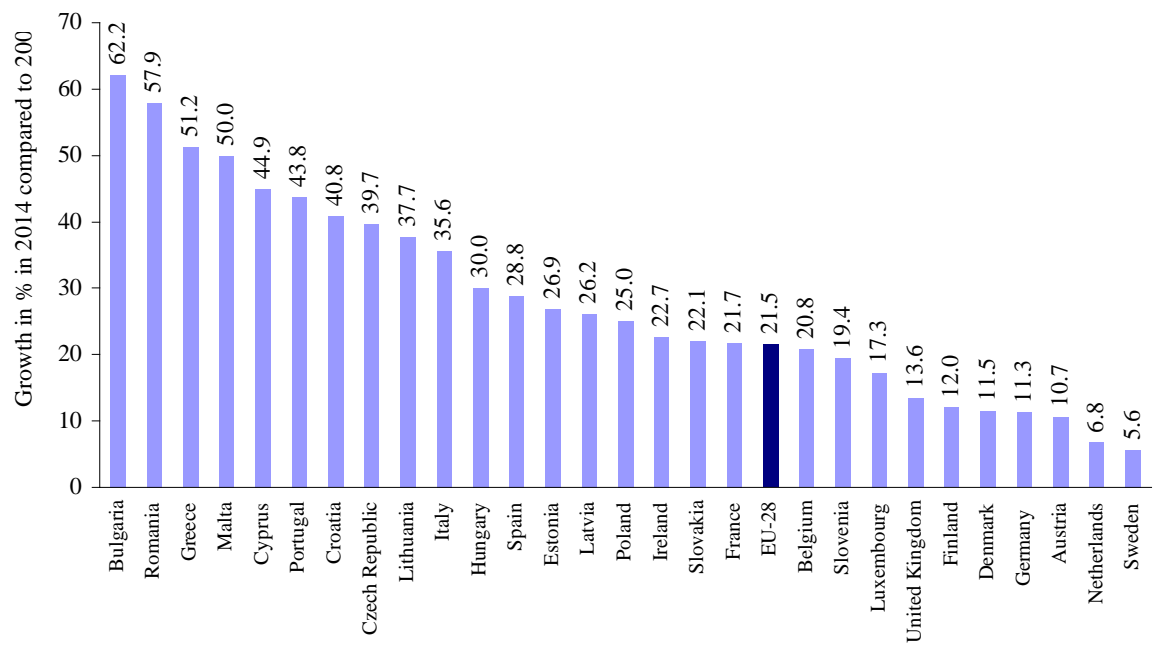

Figure 3 Evolution of the proportion of people who used the computer in total population, for the EU countries in 2014 compared to 2007

Note: are considered persons who have used the Internet in the last 12 months of the reporting period. The data refer to the population of 16-74 years Source: own processing from Eurostat

Despite the spectacular increase of people's access to technology in recent years in new EU member states, these states have continued to record values below the EU average in terms of computer usage by the population (Figure 4). This constitutes a limiting factor in the development of electronic commerce, which, however, while maintaining the growth rate of the population access to technology in these countries in recent years, will be lowered in time.

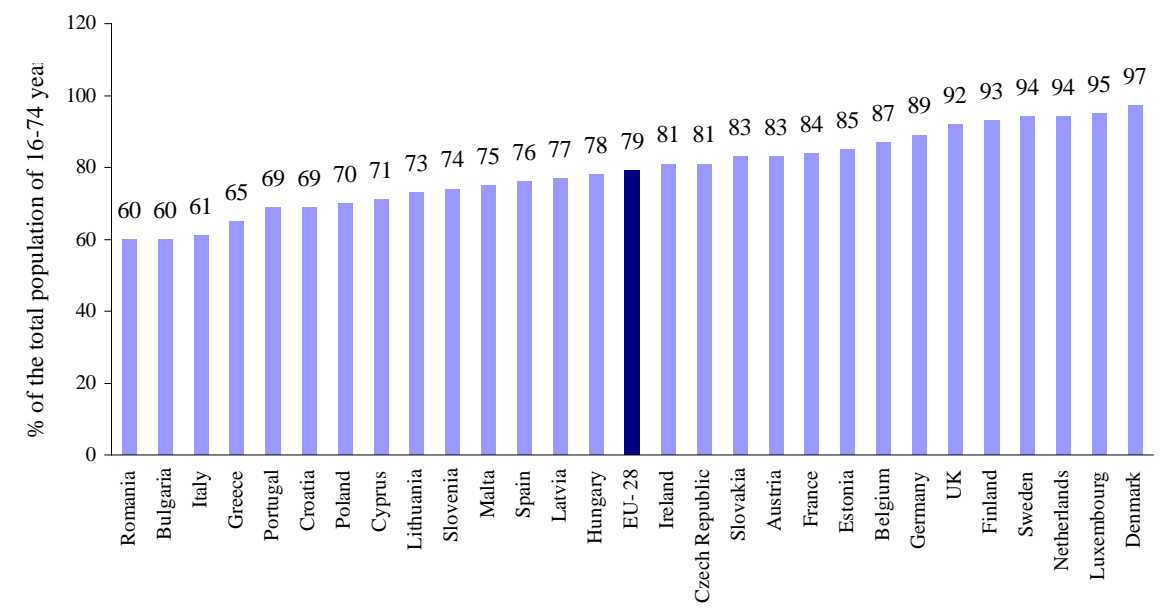

Figure 4 The share of people who used the computer in total population, in the countries of the European Union in 2014

Note: are considered people who used the computer in the last 12 months of the reporting period. The data refer to the population of 16-74 years

Source: own processing from Eurostat 


\section{The orientation of the EU population to online purchases}

In connection with the evolution of the population access to technology, the share of people who shop online in total population of 16-74 years also recorded an upward trend, from $30 \%$ in 2007 to $50 \%$ in 2014 . (Table 1)

Table 1 Evolution of the share of people who used the computer and the share of people who made online purchases in the total population and the share of those who made online purchases in all those who used the computer

\begin{tabular}{|l|c|c|c|c|c|c|c|c|}
\hline \multicolumn{2}{|c|}{ Indicator } & \multicolumn{6}{|c|}{ Year } \\
\cline { 2 - 10 } & 2007 & 2008 & 2009 & 2010 & 2011 & 2012 & 2013 & 2014 \\
\hline Percentage of individuals who used the Internet & 65 & 68 & 71 & 73 & 75 & 76 & 78 & 79 \\
\hline Percentage of individuals who ordered over the Internet & 30 & 32 & 36 & 40 & 42 & 44 & 47 & 50 \\
\hline $\begin{array}{l}\text { The share of those who made online purchases in all } \\
\text { those who used the computer }\end{array}$ & 46.2 & 47.1 & 50.7 & 54.8 & 56.0 & 57.9 & 60.3 & 63.3 \\
\hline
\end{tabular}

Source: own processing from 2015 Eurostat data

Note: are considered people who have used computer / made online purchases for private use in the last 12 months of the reporting period. The data refer to the population of 16-74 years

Considering the data for the 2007 - 2014 period, we found that the correlation between the percentage of those who used the computer and the share of those who made online purchases in the last 12 months in the EU-28 is a deterministic one, correlation ratio being closer to the value 1 .

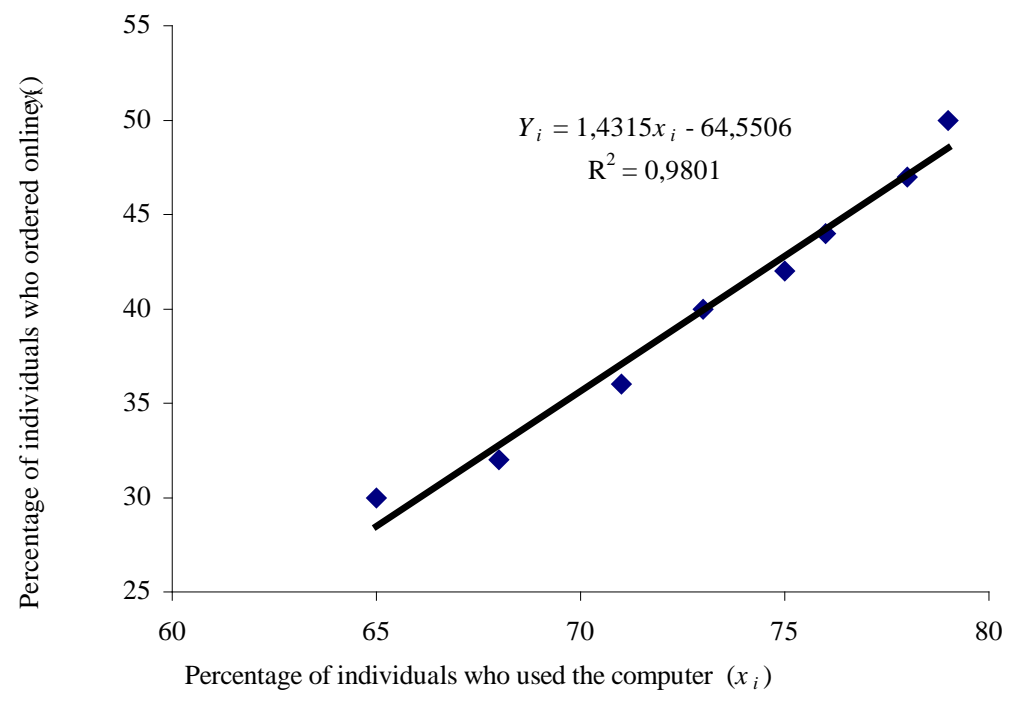

Figure 5 The relationship between the percentage of those who used the computer and the share of those who bought online in the EU - 28 in the 2007-

\section{4 period}

Source: own processing from 2015 Eurostat data

Note: are considered people who have used computer / made online purchases for private use in the last 12 months of the reporting period. The data refer to the population of 16-74 years 
Table 2 The relationship between the share of those who used the computer $\left(\mathrm{x}_{\mathbf{i}}\right)$ and the share of those who shop online $\left(y_{i}\right)$ in the $E U-28$ in the 2007-2014 period

\begin{tabular}{|c|c|c|c|c|c|c|c|}
\hline $\begin{array}{c}\text { Regression } \\
\text { equation }\end{array}$ & $\begin{array}{c}\text { Source of } \\
\text { variation }\end{array}$ & $\begin{array}{c}\text { Sum of } \\
\text { the } \\
\text { squares }\end{array}$ & $\begin{array}{c}\text { Coefficient of } \\
\text { determination }\end{array}$ & $\begin{array}{c}\text { Correlation } \\
\text { coefficient }\end{array}$ & F-Value & $\begin{array}{c}\text { Significance } \\
\text { level }\end{array}$ & $\begin{array}{c}\text { Critical } \\
\text { value } \\
\text { for the } \\
\mathrm{F} \\
\text { statistic }\end{array}$ \\
\hline $\begin{array}{c}Y_{i}=1,4315 \\
x_{i}-64,5506\end{array}$ & Total & 348,9 & \multirow{2}{*}{$98,01 \%$} & 0,99 & 295,86 & 0,05 & 5,99 \\
\cline { 2 - 6 } & Model & 342,0 & & & & \\
\cline { 2 - 3 }
\end{tabular}

Source: own processing from 2015 Eurostat data

Note: are considered people who have used computer / made online purchases for private use in the last 12 months of the reporting period. The data refer to the population of 16-74 years

Comparing the dynamics registered in the share of those who used the computer to the dynamics of the share of those who made online purchases we observe a much faster trend regarding the later indicator (21.5\% versus $66.7 \%$ in the $2007-2014$ period). This demonstrates that increasing the share of those who made online purchases was generated both by increased access to computer and by change over time of buying habits (people who although had the technology but not using to buy online, have acquired this behavior). This fact is emphasized by the increased share of those who made online purchases in all those who use computers (Table 1).

In EU countries it was found that online purchases are specific mainly to old EU countries, while in the new states, the share of those who make online purchases in all those who use the computer lies also below average.

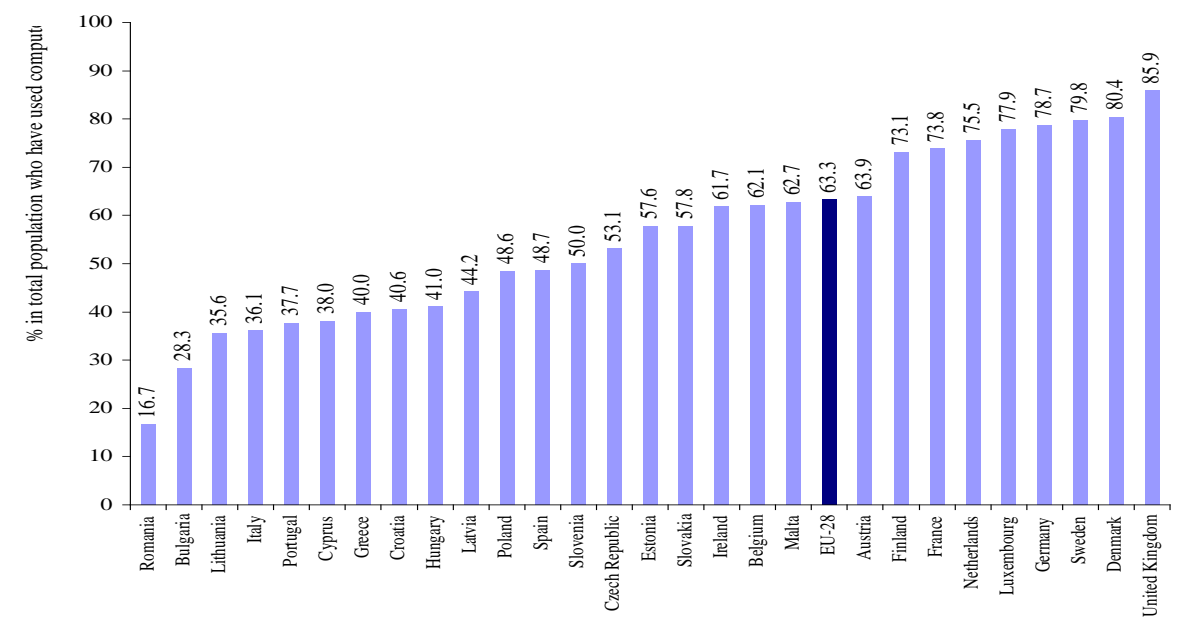

\section{Figure 6 The share of those who made online purchases in total of those who used the computer, the EU countries in 2014}

Source: own processing from 2015 Eurostat data

Note: are considered people who have used computer / made online purchases for private use in the last 12 months of the reporting period. The data refer to the population of 16-74 years

The EU countries which recorded the lowest values of the share of people shopping online in the total population of 16-74 years and the biggest increases in this indicator in recent years are generally old communist states and some of the less developed old states. Age groups who experience the greatest propensity to online purchase are 2534 years, followed by 16-24 years group and that of 35-44 years. (Table 3 ) 
Table 3 Share of population who made online purchases in the total population by age, and dynamics in 2014 compared to 2009

\begin{tabular}{|c|c|c|c|c|c|c|c|c|}
\hline \multirow{3}{*}{ Countries } & \multicolumn{7}{|c|}{$\begin{array}{c}\text { Share of population who made online purchases in } \\
\text { the total population, in } 2014\end{array}$} & \multirow{3}{*}{$\begin{array}{c}\text { The dynamics of population } \\
\text { share of } 16-74 \text { years who made } \\
\text { online purchases in the total } \\
\text { population, in } 2014 \text { compared to } \\
2007(\%)\end{array}$} \\
\hline & \multirow{2}{*}{$\begin{array}{c}\text { Total } \\
\text { population } \\
\text { (16-74 ani) }\end{array}$} & \multicolumn{6}{|c|}{ Out of which, by age } & \\
\hline & & $16-24$ & $25-34$ & $35-44$ & $45-54$ & 55-64 & $65-74$ & \\
\hline Belgium & 54 & 62 & 71 & 69 & 55 & 36 & 22 & 257.1 \\
\hline Bulgaria & 17 & 33 & 30 & 22 & 12 & 4 & 0 & 566.7 \\
\hline Czech Republic & 43 & 62 & 63 & 53 & 40 & 22 & 11 & 252.9 \\
\hline Denmark & 78 & 89 & 89 & 85 & 81 & 67 & 53 & 139.3 \\
\hline Germany & 70 & 77 & 92 & 87 & 74 & 56 & 33 & 134.6 \\
\hline Estonia & 49 & 67 & 77 & 58 & 44 & 25 & 11 & 544.4 \\
\hline Ireland & 50 & 61 & 66 & 62 & 48 & 28 & 15 & 151.5 \\
\hline Greece & 26 & 39 & 39 & 33 & 24 & 12 & 4 & 325.0 \\
\hline Spain & 37 & 45 & 54 & 49 & 37 & 20 & 7 & 205.6 \\
\hline France & 62 & 71 & 83 & 74 & 61 & 47 & 32 & 182.4 \\
\hline Croatia & 28 & 46 & 47 & 36 & 23 & 10 & 2 & 400.0 \\
\hline Italy & 22 & 29 & 34 & 30 & 22 & 13 & 5 & 220.0 \\
\hline Cyprus & 27 & 36 & 44 & 34 & 20 & 7 & 4 & 270.0 \\
\hline Latvia & 34 & 52 & 60 & 43 & 28 & 14 & 5 & 309.1 \\
\hline Lithuania & 26 & 39 & 49 & 34 & 19 & 9 & 2 & 433.3 \\
\hline Luxembourg & 74 & 71 & 85 & 80 & 73 & 68 & 55 & 157.4 \\
\hline Hungary & 32 & 47 & 47 & 44 & 29 & 17 & 6 & 290.9 \\
\hline Malta & 47 & 80 & 69 & 55 & 40 & 22 & 14 & 235.0 \\
\hline Netherlands & 71 & 83 & 87 & 79 & 72 & 61 & 38 & 129.1 \\
\hline Austria & 53 & 77 & 73 & 67 & 48 & 32 & 17 & 147.2 \\
\hline Poland & 34 & 52 & 60 & 48 & 26 & 13 & 6 & 212.5 \\
\hline Portugal & 26 & 41 & 49 & 38 & 21 & 7 & 4 & 288.9 \\
\hline Romania & 10 & 17 & 18 & 12 & 7 & 3 & 1 & 333.3 \\
\hline Slovenia & 37 & 65 & 60 & 50 & 25 & 14 & 7 & 231.3 \\
\hline Slovakia & 48 & 65 & 68 & 59 & 45 & 25 & 10 & 300.0 \\
\hline Finland & 68 & 81 & 89 & 87 & 73 & 50 & 29 & 141.7 \\
\hline Sweden & 75 & 80 & 85 & 84 & 79 & 68 & 50 & 141.5 \\
\hline United Kingdom & 79 & 83 & 90 & 88 & 81 & 70 & 53 & 149.1 \\
\hline $\begin{array}{l}\text { European Union } \\
\text { ( } 28 \text { countries) }\end{array}$ & 50 & 61 & 68 & 60 & 50 & 35 & 23 & 166.7 \\
\hline
\end{tabular}

Source: own processing from 2015 Eurostat data

Note: are considered people who have used computer / made online purchases for private use in the last 12 months of the reporting period

There is in fact a strong link between the degree of development and therefore the purchasing power of the population and the extent of Internet use to purchase goods and services in the EU countries. Thus, taking into study the levels of GDP / capita at purchasing power parity (Gross domestic product at market prices in current prices, PPS per capita) and the share of individuals who in the last 12 months of the reporting period have shopped online, in 2013 for which we have data for both indicators, it appears that at the level of the $28 \mathrm{EU}$ members, higher levels of purchasing power are associated with greater tendency of people towards online purchases. (Figure 7) 


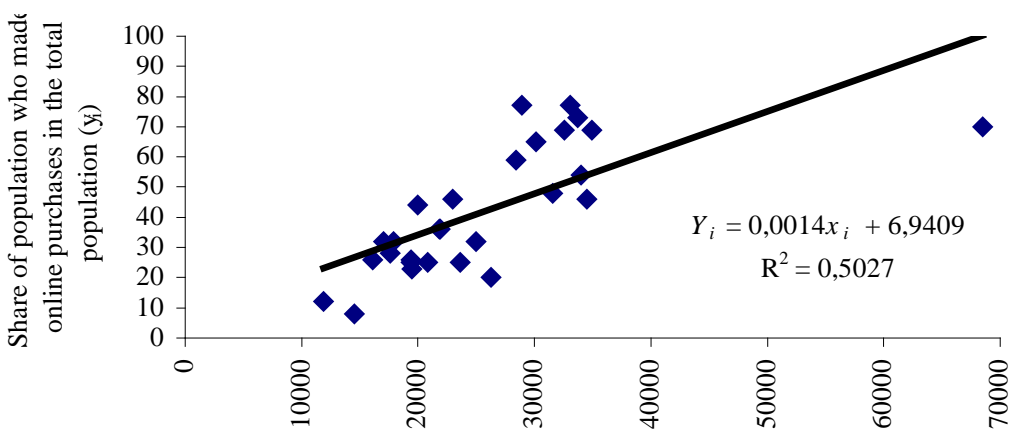

Gross Domestic Product at market prices - PPS per capita $\left(x_{i}\right)$

Figure 7 The link between Gross domestic product / capita and the share of the population who made online purchases in the total population in EU countries in 2013

Source: own processing from 2015 Eurostat data

Note: are considered people who have used computer / made online purchases for private use in the last 12 months of the reporting period.

From regression and correlation analysis there is a significant link between Gross domestic product / capita and percentage of individuals who ordered over the Internet in all EU countries, the correlation coefficient having the value of 0.709. (Table 4).

Table 4 The link between Gross domestic product / capita and the share of the population who made online purchases in total population in the EU-28, in 2013

\begin{tabular}{|c|c|c|c|c|c|c|c|}
\hline $\begin{array}{l}\text { Regression } \\
\text { equation }\end{array}$ & $\begin{array}{c}\text { Source of } \\
\text { variation }\end{array}$ & $\begin{array}{l}\text { Sum of } \\
\text { the } \\
\text { squares }\end{array}$ & $\begin{array}{l}\text { Coefficient of } \\
\text { determination }\end{array}$ & $\begin{array}{c}\text { Correlation } \\
\text { coefficient }\end{array}$ & $\begin{array}{c}\text { F- } \\
\text { Value }\end{array}$ & $\begin{array}{l}\text { Signifi- } \\
\text { cance } \\
\text { level }\end{array}$ & $\begin{array}{c}\text { Critical } \\
\text { value for the } \\
\text { F statistic }\end{array}$ \\
\hline \multirow{3}{*}{$\begin{array}{c}Y_{i}=0,0014 \\
x_{i}+6,9409\end{array}$} & Total & 11533,3 & \multirow{3}{*}{$50,27 \%$} & \multirow{3}{*}{0,709} & \multirow{3}{*}{26,28} & \multirow{3}{*}{0,05} & \multirow{3}{*}{4,22} \\
\hline & Model & 5797,3 & & & & & \\
\hline & Error & 5736,0 & & & & & \\
\hline
\end{tabular}

Source: own processing from 2015 Eurostat data

Note: are considered people who have used computer / made online purchases for private use in the last 12 months of the reporting period. We studied the value of Gross domestic product at market prices in current prices, PPS per capita

In fact, if we remove from the analysis Luxembourg, which in terms of the analyzed indicators is found to deviate from the general trend recorded in the other EU countries (see Figure 7), the link between the two analyzed indicators is one more stronger (correlation coefficient is 0.829).

Table 5 The link between gross domestic product in current prices, PPS per capita and percentage of individuals who have bought online in all EU countries (excluding Luxembourg), 2013

\begin{tabular}{|c|c|c|c|c|c|c|c|}
\hline $\begin{array}{c}\text { Regression } \\
\text { equation }\end{array}$ & $\begin{array}{c}\text { Source of } \\
\text { variation }\end{array}$ & $\begin{array}{c}\text { Sum of } \\
\text { the } \\
\text { squares }\end{array}$ & $\begin{array}{c}\text { Coefficient of } \\
\text { determination }\end{array}$ & $\begin{array}{c}\text { Correlation } \\
\text { coefficient }\end{array}$ & $\begin{array}{c}\text { F- } \\
\text { Value }\end{array}$ & $\begin{array}{c}\text { Signifi- } \\
\text { cance } \\
\text { level }\end{array}$ & $\begin{array}{c}\text { Critical } \\
\text { value for the } \\
\text { F statistic }\end{array}$ \\
\hline \multirow{2}{*}{$\mathrm{Y}_{\mathrm{i}}=0,0024$} \\
$\mathrm{X}_{\mathrm{i}}+18,0033$ & Total & 10734,7 & \multirow{2}{*}{$68,69 \%$} & 0,829 & 54,86 & 0,05 & \multirow{2}{*}{4,24} \\
\cline { 2 - 3 } & Model & 7374,1 & Error & 3360,6 & & 0,24 & \\
\hline
\end{tabular}

Source: own processing from 2015 Eurostat data

Note: are considered people who have used computer / made online purchases for private use in the last 12 months of the reporting period. We studied the value of Gross domestic product at market prices in current prices, PPS per capita 


\section{Percentage of turnover from e-commerce on enterprises' total turnover}

The development of this form of trade is reflected in the evolution of the turnover from e-commerce of EU organizations. Thus, in 2010, 14\% of the turnover of companies with over 10 employees (excluding the financial sector) was obtained from electronic trade, a share that reached 15\% in 2014. There is big difference, however, between EU members in this regard. Thus, from table 6 is seen that this is not a generalized phenomenon (countries like Lithuania, Germany, Netherlands, and Denmark recording declines in terms of the analyzed indicator). A dramatic increase in this indicator was recorded by Cyprus where turnover from e-commerce on enterprises' total turnover was raised by 8 times. It is found that in almost all EU countries there is a certain relationship between firm size and the percentage of turnover from e-commerce on enterprises' total turnover. Thus, except for Estonia, Cyprus, Latvia and Lithuania, in all other EU countries for which data are available, the lowest share of turnover from e-commerce were recorded in the category of small enterprises and higher levels in the category of large enterprises.

Table 6 Percentage of turnover from e-commerce on enterprises' total turnover, on some of the EU countries in 2014, and dynamics compared to 2010

\begin{tabular}{|c|c|c|c|c|c|}
\hline \multirow[b]{2}{*}{ Countries } & \multicolumn{4}{|c|}{$\begin{array}{l}\text { Percentage of turnover from e-commerce on enterprises' total turnover } \\
\qquad\left({ }^{*} \text { without financial sector) }\right.\end{array}$} & \multirow{2}{*}{$\begin{array}{l}\text { Dinamics of percentage of } \\
\text { turnover from e-commerce on } \\
\text { enterprises' total turnover (All } \\
\text { enterprises with } 10 \text { persons } \\
\text { employed or more) in } 2014 \\
\text { compared to } 2010(\%) \\
\end{array}$} \\
\hline & \begin{tabular}{|c|} 
All enterprises \\
with 10 persons \\
employed or more
\end{tabular} & $\begin{array}{c}\text { Small enterprises } \\
\text { (10-49 persons } \\
\text { employed) }\end{array}$ & $\begin{array}{c}\text { Medium } \\
\text { enterprises (50- } \\
249 \text { persons } \\
\text { employed) }\end{array}$ & \begin{tabular}{|c|} 
Large enterprises \\
(250 persons \\
employed or \\
more)
\end{tabular} & \\
\hline Bulgaria & 3 & 1 & 2 & 6 & 150,0 \\
\hline Czech Republic & 29 & 15 & 21 & 37 & 152,6 \\
\hline Denmark & 16 & 11 & 18 & 19 & 94,1 \\
\hline Germany & 13 & 7 & 11 & 15 & 72,2 \\
\hline Estonia & 18 & 16 & 12 & 25 & 163,6 \\
\hline Ireland & 52 & 28 & 45 & 63 & 216,7 \\
\hline Greece & 2 & n.d. & 3 & 3 & n.d. \\
\hline \begin{tabular}{|l} 
Spain \\
\end{tabular} & 15 & 5 & 11 & 21 & 136,4 \\
\hline France & 15 & 6 & 14 & 20 & 115,4 \\
\hline Croatia & 13 & 10 & 12 & 14 & 144,4 \\
\hline Italy & 7 & 2 & 8 & 11 & 140,0 \\
\hline Cyprus & 8 & 13 & 6 & 3 & 800,0 \\
\hline \begin{tabular}{|l} 
Latvia \\
\end{tabular} & 8 & 3 & 13 & 10 & 114,3 \\
\hline Lithuania & 7 & 4 & 11 & 8 & 50,0 \\
\hline Hungary & 20 & 4 & 9 & 32 & 125,0 \\
\hline Malta & 9 & 2 & 5 & 22 & n.d. \\
\hline Netherlands & 12 & 5 & 8 & 17 & 85,7 \\
\hline Austria & 13 & 4 & 9 & 22 & 100,0 \\
\hline Poland & 12 & n.d. & n.d. & 18 & 150,0 \\
\hline Romania & 6 & 4 & 5 & 8 & 150,0 \\
\hline Slovakia & 13 & 4 & 8 & 19 & 118,2 \\
\hline Finland & 19 & n.d. & n.d. & n.d. & 105,6 \\
\hline Sweden & 18 & 9 & 18 & 22 & 100,0 \\
\hline United Kingdom & 20 & 6 & 10 & 26 & 125,0 \\
\hline \begin{tabular}{|l} 
European Union \\
$(28$ countries $)$
\end{tabular} & 15 & 6 & 11 & 20 & 107,1 \\
\hline
\end{tabular}

Source: own processing from 2015 Eurostat data

\section{Percentage of enterprises selling online on total enterprises}

Closely related to the shown indicator (Percentage of turnover from e-commerce on enterprises' total turnover), the proportion of businesses selling online in all EU-28 enterprises has been growing in recent years. Thus, referring to firms with over 10 employees (excluding the financial sector), $15 \%$ of these sales were made online in 2014 (minimum 1\% of turnover), compared to 13\% in 2010. Percentage of enterprises selling online on total enterprises by size confirms that greater orientation towards 
electronic commerce is at the level of large enterprises, followed by the medium ones. (Table 7)

Table 7 Percentage of enterprises selling online (at least $1 \%$ of turnover) on total enterprises with 10 persons employed or more (without financial sector), in 2010-

\section{4 period}

\begin{tabular}{|l|c|c|c|c|c|}
\hline \multirow{2}{*}{ Categories of enterprises (without financial sector) } & \multicolumn{5}{|c|}{ Years } \\
\cline { 2 - 7 } & 2010 & 2011 & 2012 & 2013 & 2014 \\
\hline Small enterprises (10-49 persons employed) & 12 & 11 & 12 & 13 & 13 \\
\hline Medium enterprises (50-249 persons employed) & 20 & 20 & 22 & 22 & 22 \\
\hline Large enterprises (250 persons employed or more) & 31 & 32 & 35 & 35 & 35 \\
\hline All enterprises, (10 persons employed or more) & 13 & 13 & 14 & 14 & 15 \\
\hline
\end{tabular}

Source: own processing from 2015 Eurostat data

\section{Categories of goods or services ordered over the Internet}

As regards goods purchased online there is a greater propensity to purchase clothes and sporting goods at EU-28, 59\% of 16-74 years population making Internet purchases of such goods (at least one purchase in the last year of the reporting period). Also, household goods, tickets for events, books / magazines / e-learning are among the categories of products purchased by a larger proportion of the EU population. (Table 8)

Table 8 Percentage of individuals who ordered goods or services, over the Internet, for private use in 2014, in the last year

\begin{tabular}{|c|c|c|c|c|c|c|c|c|c|c|}
\hline \multirow[b]{2}{*}{ Countries } & \multicolumn{10}{|c|}{ Categories of goods or services } \\
\hline & $\begin{array}{c}\text { Food/ } \\
\text { groceries }\end{array}$ & $\begin{array}{l}\text { Clothes, } \\
\text { sports } \\
\text { goods }\end{array}$ & $\begin{array}{l}\text { Electronic } \\
\text { equipment }\end{array}$ & $\begin{array}{l}\text { Computer } \\
\text { software }\end{array}$ & $\begin{array}{l}\text { Computer } \\
\text { hardware }\end{array}$ & $\begin{array}{c}\text { Shares/ } \\
\text { financial } \\
\text { services/ } \\
\text { insurance }\end{array}$ & $\begin{array}{l}\text { Films/ } \\
\text { music }\end{array}$ & $\begin{array}{c}\text { Household } \\
\text { goods }\end{array}$ & $\begin{array}{c}\text { Tickets for } \\
\text { events }\end{array}$ & \begin{tabular}{|c|} 
Books/ \\
magazines \\
/e-learning \\
material
\end{tabular} \\
\hline Belgium & 9 & 47 & 17 & 18 & 11 & 6 & 21 & 26 & 39 & 27 \\
\hline Bulgaria & 20 & 73 & 19 & 7 & 9 & 2 & 8 & 31 & 15 & 13 \\
\hline Czech Republic & 6 & 52 & 27 & 6 & 4 & 4 & 5 & 12 & 35 & 16 \\
\hline Denmark & 15 & 58 & 29 & 21 & 28 & 17 & 38 & 40 & 66 & 31 \\
\hline Germany & 15 & 67 & 37 & 30 & 31 & 10 & 38 & 52 & 44 & 52 \\
\hline Estonia & 13 & 53 & 20 & 11 & 13 & 21 & 12 & 30 & 50 & 20 \\
\hline Ireland & 10 & 55 & 29 & 15 & 8 & 16 & 32 & 26 & 59 & 38 \\
\hline Greece & 6 & 51 & 31 & 4 & 18 & 2 & 6 & 18 & 17 & 13 \\
\hline Spain & 14 & 43 & 22 & 17 & 22 & 8 & 14 & 26 & 42 & 29 \\
\hline France & 18 & 57 & 13 & 20 & 22 & 5 & 20 & 37 & 29 & 34 \\
\hline Croatia & 5 & 48 & 22 & 9 & 24 & 4 & 7 & 24 & 18 & 23 \\
\hline Italy & 6 & 35 & 21 & 15 & 9 & 6 & 13 & 26 & 21 & 31 \\
\hline Cyprus & 11 & 61 & 24 & 10 & 23 & 2 & 4 & 11 & 13 & 14 \\
\hline Latvia & 4 & 48 & 30 & 4 & 18 & 28 & 7 & 29 & 32 & 10 \\
\hline Lithuania & 13 & 59 & 17 & 8 & 13 & 14 & 11 & 33 & 42 & 15 \\
\hline Luxembourg & 15 & 50 & 28 & 33 & 20 & 8 & 37 & 32 & 52 & 62 \\
\hline Hungary & 11 & 49 & 29 & 8 & 11 & 3 & 11 & 29 & 27 & 29 \\
\hline Malta & 4 & 66 & 30 & 25 & 29 & 7 & 22 & 24 & 29 & 36 \\
\hline Netherlands & 21 & 63 & 32 & 32 & 15 & 10 & 28 & 37 & 55 & 50 \\
\hline Austria & 13 & 62 & 33 & 25 & 21 & 4 & 28 & 31 & 38 & 49 \\
\hline Poland & 24 & 61 & 19 & 14 & 14 & 4 & 12 & 42 & 16 & 26 \\
\hline \begin{tabular}{|l|} 
Portugal \\
\end{tabular} & 16 & 42 & 18 & 30 & 7 & 11 & 21 & 21 & 23 & 32 \\
\hline Romania & 6 & 58 & 21 & 9 & 11 & 3 & 15 & 16 & 18 & 29 \\
\hline Slovenia & 24 & 53 & 22 & 11 & 28 & 5 & 10 & 37 & 34 & 27 \\
\hline Slovakia & 10 & 61 & 18 & 8 & 6 & 3 & 10 & 40 & 16 & 30 \\
\hline Finland & 5 & 65 & 27 & 27 & 23 & 27 & 31 & 29 & 56 & 36 \\
\hline Sweden & 12 & 60 & 23 & $:$ & 26 & 26 & 34 & 30 & 66 & 45 \\
\hline United Kingdom & 32 & 67 & 34 & 32 & 19 & 29 & 43 & 57 & 48 & 46 \\
\hline \begin{tabular}{|l|}
$\begin{array}{l}\text { European Union } \\
(28 \text { countries) }\end{array}$ \\
\end{tabular} & 18 & 59 & 27 & 24 & 21 & 13 & 28 & 41 & 40 & 39 \\
\hline
\end{tabular}

Source: own processing from 2015 Eurostat data 


\section{Conclusions}

The European market for e-commerce has shown a strong dynamics, as reflected in both turnover in this category of commercial activity, as well as in the growing number of consumers that purchases online. Market expansion was generated as a result of increased access of the population to technology, and by acquiring the habit of online buying by a increasing number of EU consumers. Thus, according EMOTA, turnover of e-commerce at European level increased from 185 Billion Euros in 2009 to 352 Billion Euros in 2013. Also at EU level, the share of those who made online purchases increased by $38.9 \%$ during $2009-2014$ and by $66.7 \%$ in the period 2007 2014, and the share of turnover from electronic commerce of businesses with over 10 employees (excluding the financial sector) increased from $14 \%$ in 2010 to $15 \%$ in 2014. The main categories of products purchased online are: clothes and sports goods, household goods, tickets for events, books / magazines / e-learning.

\section{References}

Kumar V., Aaker, D.A., Day G.S. (1999), Essentials of Marketing research, John Wiley \& Sons, Inc., New York Chichester Weinheim Brisbane Singapore Toronto.;

Zaiţ, L. (2013), Managementul marketingului în contextul globalizării piețelor, Editura Alma Mater, Bacău

EMOTA (European Multi-channel and Online Trade Association), E-commerce and Distance Selling in Europe Report, available at http://www.emota.eu/

Eurostat, available at http://ec.europa.eu/eurostat/data/database 